\title{
POPULATION AGEING AND WELFARE DISSIMILARITIES WITHIN THE EUROPEAN UNION: A NEW APPROACH BASED ON CLUSTER ANALYSIS
}

UDC 330.342(4-672EU)

\author{
Mirela Cristea $^{1}$, Grațiela Georgiana Noja ${ }^{2}$, Yannis Thalassinos ${ }^{3}$ \\ ${ }^{1}$ University of Craiova, Faculty of Economics and Business Administration, \\ Craiova, Romania \\ ${ }^{2}$ West University of Timişoara, Faculty of Economics and Business Administration, \\ East European Center for Research in Economics and Business, Timişoara, Romania, \\ ${ }^{3}$ Gulf University in Science and Technology, Kuwait, Kuwait
}

\begin{abstract}
The research aims to identify several dissimilarities between the European Union Member States (EU-27 MS) in terms of welfare and labour market dimensions under the sheer implications of the ageing phenomenon. The quantitative research methodology emphasizes the cluster analysis based on the Ward method, performed for the year 2018. Main results denote that only two countries (Denmark and Sweden) registered soaring performances, especially for the labour market credentials (particularly the employment rate and active policies). Other 10 EU-27 MS accounted medium performances in terms of well-being, but also the lowest achievements as regards the old dependency rate, the employment rate of persons aged 55-64 and the birth rate. This paper brings to the fore the keen need to redesign specific policies and tailored strategies by the responsible authorities and business representatives across the $E U$, in order to enhance achievements and new solutions for the difficulties brought by population ageing, with spillover effects on the labour market integration of older employees and overall economic welfare. The study stands out through the new integrative approach based on cluster analysis that underlines the dissimilarities between the EU member states, and the features of each group of countries, in a pre-settled framework, thus grasping the difficulties, but also the opportunities faced in terms of ageing and economic welfare.
\end{abstract}

Key words: labour market, economic development, demographic economics, cluster analysis

JEL Classification: J14, J01, I31

Received December 26, 2020 / Accepted Januray 11, 2021

Corresponding author: Grațiela Georgiana Noja

West University of Timişoara, Faculty of Economics and Business Administration, East European Center for Research in Economics and Business, Timişoara, Romania

E-mail: gratiela.noja@e-uvt.ro 


\section{INTRODUCTION}

Population ageing represents a topical subject on the European and global agenda, being placed in the open conversation on the transition to old societies that is already well under way, since the proportion of youg people has diminished compared to a few decades ago, while the share of early retirees has significantly increased (Sidlo et al., 2020; Wolf, 2020). These challenges are amplified today in the face of the Covid-19 pandemic crisis (Kashnitsky \& Aburto, 2020; McKibbin \& Fernando, 2020), while the globalization process weakens, and also the labour force shrinks since the growth of the working-age population is severely slowing in the core of the world economy (Skufina et al., 2020), and, particularly, in the European economies (Calvo-Sotomayor et al., 2019; Cristea et al, 2020a; Jivraj et al., 2020).

The European Union-wide reference study on grouping the Member States (MS) according to the representative indicators of population ageing measurement is the one deployed by the United Nations Economic Commission for Europe (UNECE) and European Commission (EC) (UNECE/EC, 2019), considering the Active Ageing Index (AAI) at the level of 2018. The AAI represents a composite indicator, including 22 indicators, grouped in four domains, namely, "employment, participation in society, independent healthy and secure living, and capacity and enabling environment for active ageing" (UNECE/EC, 2019, p. 17). As stated by in this report, the European Union (EU) MS were grouped according to the similar characteristics in terms of AAI, resulting in 4 groups of countries relative to the EU average (35.8), with scores between 28.1 - in the case of Greece, and 46.9 - in the case of Sweden. Moreover, in order to measure the existing inequalities between the EU MS, in this report, the AAI was connected for each country "to the GDP per capita, Gini index and life satisfaction of older people in the EU28" (UNECE/EC, 2019, p. 54), resulting in significant differences among them.

In this frame of reference, current paper aims to advance the UNECE/CE (2019) study by deploying a cluster analysis across the EU-27 MS, at the level of 2018, in order to assess the interlinkages between population ageing, labour market outcomes and welfare dissimilarities, and to propose specific policies and strategies for each group of countries.

After a concise introduction on the research topic, the paper presents a synthesis of the main results obtained in the literature, focused on the implications of demographic ageing on the labour market and economic development, as well as differences and similarities between states, based on these coordinates. Then follows the description of the data and the research methodology used, respectively the cluster analysis by the Ward method. The obtained results and the discussions are related to those obtained in the specialized literature and are supported by the data from the Annex. The conclusions summarize the rendering of the research hypothesis and the main strategies and policies proposed for each group of states.

\section{BRIEF LITERATURE REVIEW}

The connections between demographic ageing, the labour market and the degree of economic development of countries have been intensely debated in the literature. A number of studies have highlighted the unfavorable implications of the ageing population on labour productivity and, implicitly, on economic growth in all regions of the world.

Thereby, in the United States of America (USA), Maestas et al. (2016) showed that an increase in the stock of population aged over 60 years by $10 \%$ generates a reduction in the Gross Domestic Product (GDP) growth rate per capita by $5.5 \%$, due to the lower increase of labour 
productivity by age groups, concomitant with the easy-going increase of the working age population. At the EU-28 level, Cristea et al. (2020a) showed that the unfavorable implications of demographic ageing (measured by the workforce group aged between 55-64 years) on labour productivity were manifested only in countries that registered the AAI below the EU average or slightly above it. Similar conclusions were drawn by Calvo-Sotomayor et al. (2019) for 24 EU countries, namely the workforce ageing has negatively influenced the labour productivity for the analysed period 1983-2014. The confined analysis only for the new EU countries (EU13) revealed that labour productivity in these countries "is shaped under the complex implications of older employment and ageing dimensions, further connected to health and wellbeing", with unfavourable implications if proper policies and strategies would not be implemented (Cristea et al., 2020b, p. 74).

Conde-Sala et al. (2016, p. 1059), studying the perceived life quality of people aged over 65 years at the European level, based on the results of the Survey of Health, Aging and Retirement in Europe (SHARE) in 2013, revealed that the percieved life is much better felt in the cluster of the Nordic countries (with a social democratic model), but also at the level of Continental countries, which have a "corporate model" (characterized by better socio-economic indicators), compared with clusters comprising the Eastern European countries and from the Mediterranean area (which have lower socio-economic indicators). Due to heteregeneity among the European countries, Suchecka and Urbaniak (2016, p. 173) proved that "it is possible to divide European countries on the basis of similarities of the status of people aged 65+", related to the economic and social conditions, with common strategies and policies for each group of countries (clusters). Authors (Suchecka \& Urbaniak, 2016) found similarities at the year of 2012, by applying cluster analysis, as regards health and ageing dimensions among Switzerland, Sweden and Norway, on the one hand, and Central and Eastern European countries, on the other hand. Carrying out an analysis at the level of EU countries regarding the way in which active ageing (measured by AAI) correlates with the degree of economic development (measured by the GDP per capita and labour productivity), the dimensions of the labour market and other representative indicators of demographic ageing (old dependency ratio) at the level of 2018, Thalassinos et al. (2019, p. 598) concluded that "the lowest performance in terms of ageing, welfare and labour market policies was registered by the EU-13 countries (including also Greece and Portugal), and the highest, by countries from the old EU-15, especially by the Nordic States (Sweden, Denmark, Finland)".

The analysis of the Slovenian regions grouping, made by Rovan and Sambt (2003) by applying the cluster methodology, based on demographic factors (population ageing, population growth rate and migration) and certain socio-economic variables available at the territorial level (such as per capita income tax base, unemployment rate, population employed in agriculture, tertiary education and the car park), revealed that the most developed regions were characterized by a demographic ageing and a higher rate of lower unemployment, while in the less developed regions the situation was reversed. These results point out the same unfavorable dependence between population ageing and the degree of economic development of the country.

As such, the main results in the literature show significant differences between countries or regions in terms of the economy's response to the demographic ageing, for which there are different measurement units. In addition, the researchers show that the countries' homogeneity in terms of demographic ageing and well-being is changing from one period to another (Suchecka \& Urbaniak, 2016). 


\section{DATA AND METHODOLOGY}

By reviewing the relevant underpinnings of the literature related to our own research subject, we have grouped the data into three categories of indicators, namely: welfare variable, ageing credentials and labour market specific indicators, as follows:

(i) Welfare indicator: Gross Domestic Product (GDP) per capita $\left(G D P \_C\right)$ (measured in constant 2010 United States Dollars - USD), for which the data were extracted from the World Development Indicators (WDI) (The World Bank, 2020);

(ii) Ageing representative indicators: Old age dependency ratio (OD_65) as share of population over 65 years aged to active population (15-64 years) (\%); Life expectancy at birth total population $(L E)$ (years); Crude birth rate $(B R)$ (measured in "number of live births per 1,000 persons"), with data extracted from the Eurostat (European Commission, 2020a);

(iii) Labour market specific indicators: Employment rate, 55-64 years aged group or workforce ageing (ER_55_64) (\% of total population), data extracted from the Eurostat (European Commission, 2020a); Active labour market policies (ALMP) (\% of GDP) and Passive labour market policies (PLMP) (\% of GDP), with data extracted from the Employment, Social Affairs \& Inclusion (European Commission, 2020b).

The analysis is performed at the level of EU-27 for 2018.

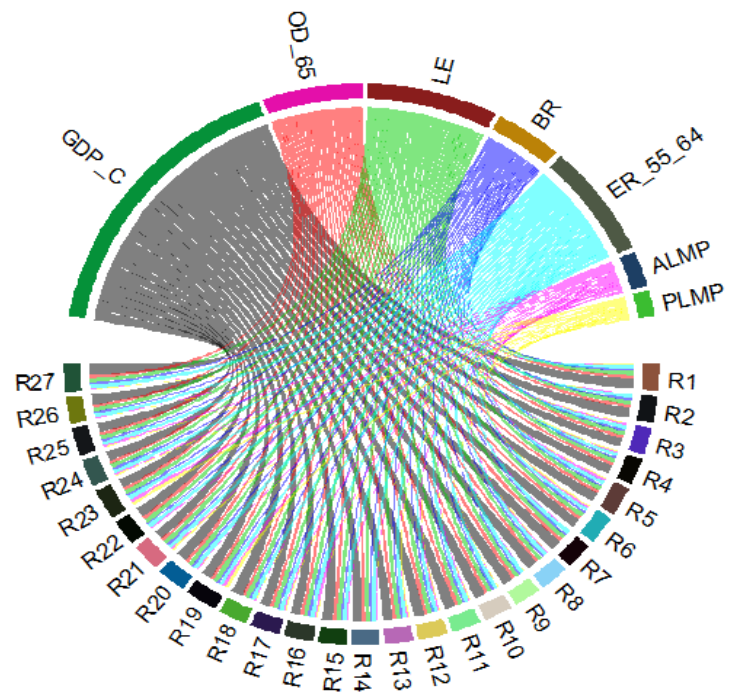

Fig. 1 Chord diagrams of the indicators used in the cluster analysis, EU-27, 2018

Legend: R1-Austria, R2-Belgium, R3-Bulgaria, R4-Croatia, R5-Cyprus, R6-Czech Republic, R7Denmark, R8-Estonia, R9-Finland, R10-France, R11-Germany, R12-Greece, R13-Hungary, R14Ireland, R15-Italy, R16-Latvia, R17-Lithuania, R18-Luxembourg, R19-Malta, R20-Netherlands, R21Poland, R22-Portugal, R23-Romania, R24-Slovak Republic, R25-Slovenia, R26-Spain, R27-Sweden. Source: own configuration in $\mathrm{R}$ version 3.6.3, based on the compiled dataset from Eurostat (European Commission, 2020a)

Taking a closer look at the data (Fig. 1), at a glance, we could observe that there are important welfare dissimilarities across the EU, particularly as regards the ageing population and labour market indicators. 
In terms of the economic development, measured by the GDP per capita (Fig. 2), the gap across the EU-27 countries between the poorest country (Bulgaria) and the richest one (Luxembourg), in 2018, is over 100 thousand USD. We can see that the highest welfare levels were obtained by the old EU countries and the lowest by the new EU countries (that adhered to the EU after 2004).

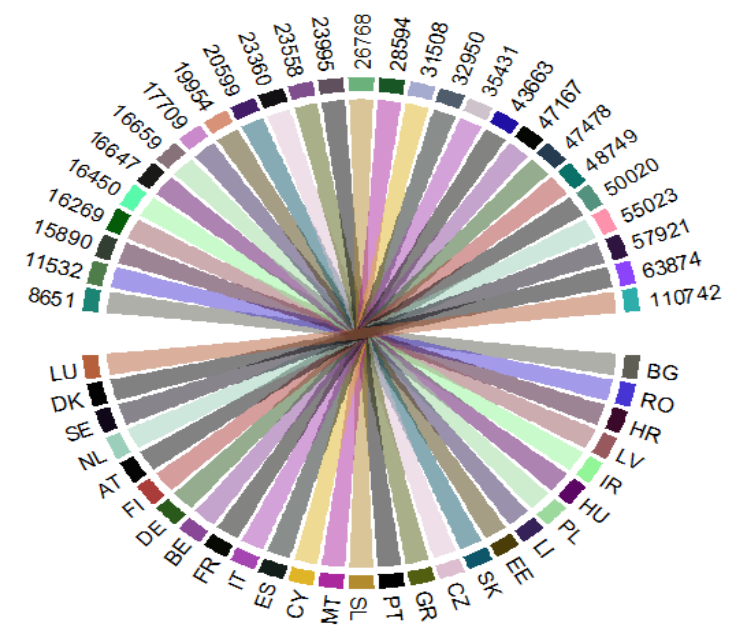

Fig. 2 GDP per capita (constant 2010 USD), EU-27, 2018 Source: own configuration in $\mathrm{R}$ version 3.6.3, based on the compiled dataset from Eurostat (European Commission, 2020a)

At the same time, the old-age-dependency ratio per 100 persons (Fig. 3), namely "the ratio between the number of persons aged 65 and over (age when they are generally economically inactive) and the number of persons aged between 15 and 64" (European Commission, 2020a), is significantly high in Italy, Finland, Greece, Portugal, Germany, approaching $35 \%$ in 2018, while in Luxembourg, Ireland this ration is about $20 \%$.

The old dependency ratio in the EU-27 (Fig. 3(a)) shows a share of $21 \%$ between people over 65 years old and the working population group, aged 15-64 years, registered in Luxembourg, and $35 \%$ in Italy. Increased old dependency ratios within the EU induce important long-run economic consequences, in terms of the savings and investment, housing markets or consumption patterns. The highest life expectancy (Fig. 3(b)) is in Spain (83.5 years), while the lowest is in Bulgaria (75 years), and the birth rate (Fig. 3(c)) is more pronounced in Ireland, Sweden and France (over 11 live births per 1,000 persons), while the less is in Italy Spain and Greece (between 7.3 - 8.1 live births per 1,000 persons).

The long-term problematic issues caused by a decrease in the labour force stock, due to decreasing of the birth rate, and an increase in the age dependency ratio could be alleviated by targeted policies designed to increase productivity and the labour market participation of the elderly. 

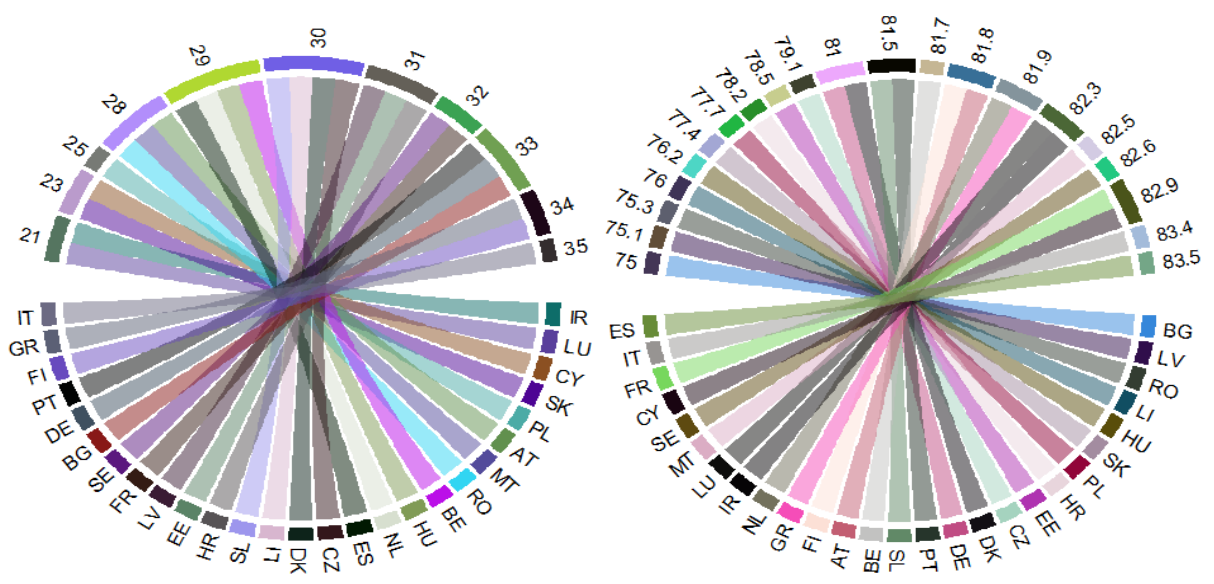

(a)

(b)

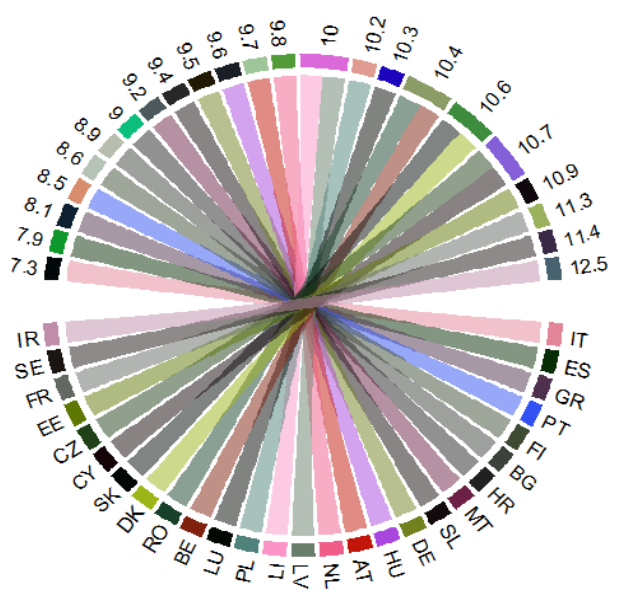

(c)

Fig. 3 Old-age-dependency ratio $\left(O D \_65\right)$ (a), Life expectancy (LE) (b) and Birth rate (BR) (c), EU-27, 2018

Source: own configuration in $R$ version 3.6.3, based on the compiled dataset from Eurostat (European Commission, 2020a)

In the same perspective, in 2018, the employment rate of the population aged between 55-64 years (Fig. 4(a)) reached 78\% in Sweden, while at the opposite end across the EU MS we find Greece, Luxembourg, Croatia and Romania, where this rate is only slightly around $40 \%$. Progresses still therefore need to be made in this respect by most of the EU countries, particularly from Central and Eastern Europe. Labour market policies allocation in GDP (active and passive) is at the highest in Denmark and Sweden (Fig. 4(b)), as regards ALMP, and in the Netherlands, Austria, Finland and Belgium (Fig. 4(c)), regarding PLMP. The 
lowest participation of labour market policies in GDP is in Romania and Cyprus (Fig. 4(b)), considering ALMP, and Malta and Romania (Fig. 4(c)), as regards PLMP.

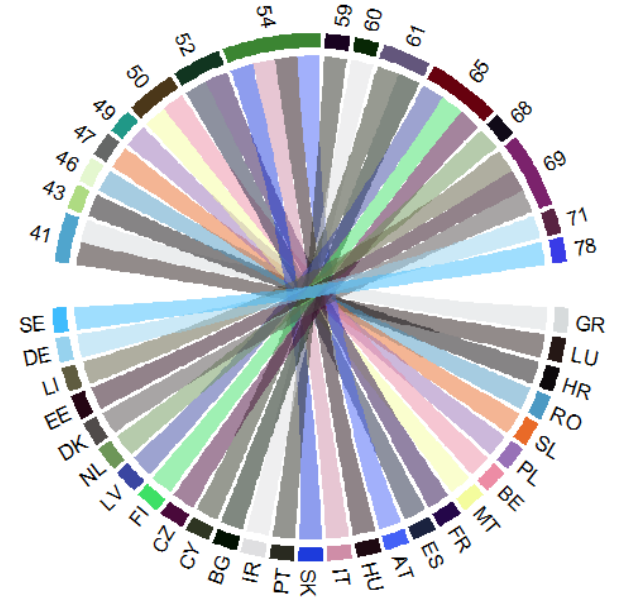

(a)

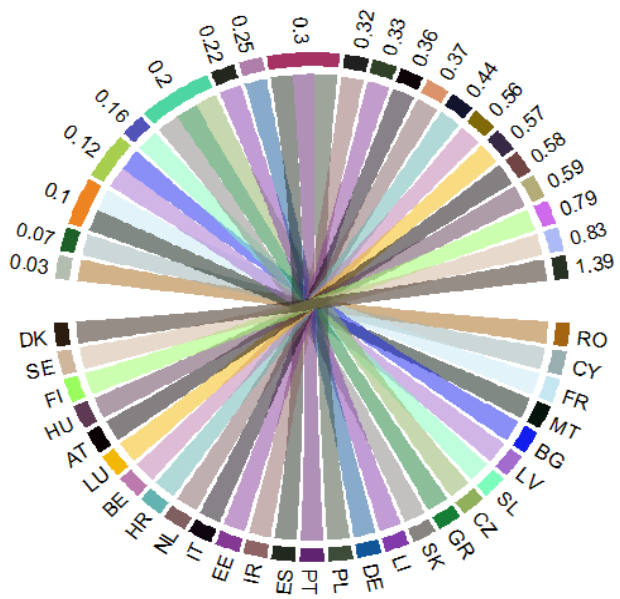

(b)

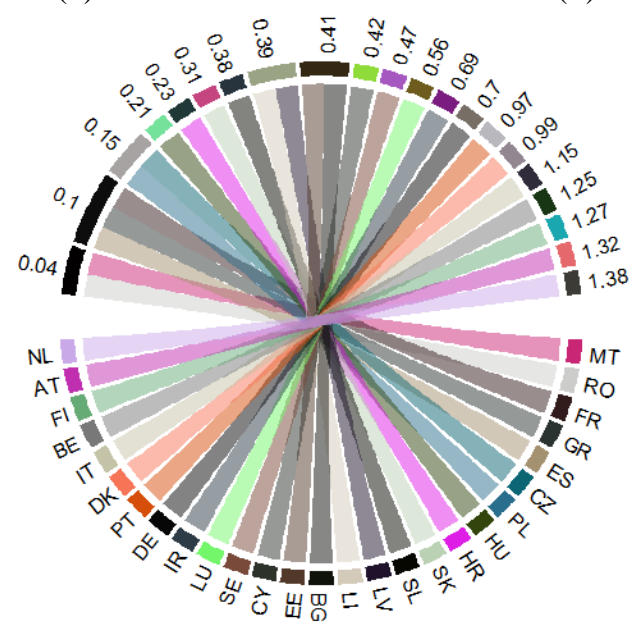

(c)

Fig. 4 Employment rate of the population aged from 55 to 64 years (ER_55_64) (a), $\operatorname{ALMP}(\mathrm{b}), \operatorname{PLMP}(\mathrm{c}), \mathrm{EU}-27,2018$

Source: own configuration in R version 3.6.3, based on the compiled dataset from Eurostat (European Commission, 2020a)

We have therefore focused our research methodology, based on cluster analysis, on these credentials, processed through the Stata program, in order to bring new evidence on the interlinkages between population ageing, labour market indicators and economic welfare dissimilarities across the EU member states, at the level of 2018. The cluster forming and analysis is based on the Ward method inset on hierarchical clusters (Härdle 
\& Simar, 2019), which set out that "the distance between two clusters A and B is shown by how much the sum of squares will increase when they are cumulated" (Cornish, 2007, p. 3). The data was adjusted by standardisation and logarithm in order to ensure a proper comparability between variables.

Accordingly, based on the literature review and own methodological endeavour, we pursued to verify the following research hypothesis $(\mathrm{H})$ : "There are significant dissimilarities between the EU-27 MS in terms of welfare, ageing phenomenon and labour market implications, the developing EU countries confronting with low performances compared to the developed ones".

\section{RESULTS AND DISCUSSIONS}

We have verified our hypothesis, $H$, by applying the cluster modelling, processed through the Ward method. Thus, we aim to group the EU-27 countries corresponding to the economic welfare (measured by GDP per capita), the ageing phenomenon dimensions (OD_65, LE and $B R)$ and labour market indicators (ER_55_64, ALMP and PLMP) at the level of 2018.

The correlation matrix of the considered variables and dendrogram of cluster forming for EU-27 MS, at the level of 2018, are presented in Fig. 5(a), respectively Fig. 5(b).

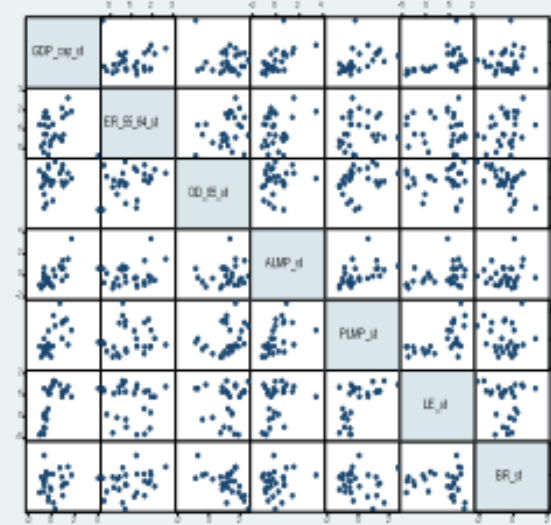

(a)

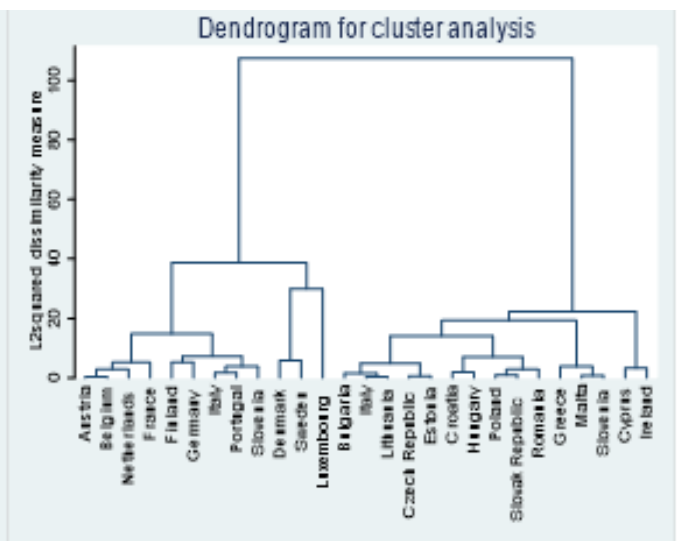

(b)

Fig. 5 Correlation matrix (a) and dendrogram of cluster modelling in terms of working ageing (b), EU-27, 2018

Source: own process of panel data in Stata

The performances achieved by each country, as revealed the $G D P \_C$, ageing phenomenon dimensions and labour market indicators (Table 1, Appendix, Table A1) have denoted that in few countries from the developed EU MS (grouped into cluster C2), namely Denmark and Sweden, there are very high performances, especially for ER_55_64 (the mean is 2.2866) and $A L M P$ (the mean is 2.4618). These results are similar to those obtained by Thalassinos et al. (2019) (based on AAI), and Suchecka and Urbaniak (2016) (applied for the year 2012).

For the 10 countries of the EU-27 MS (grouped into clusters C1 and C3), there were registered medium performances in terms of well-being, ageing process and labour market 
policies, the lowest $O D \_65, E R \_55 \_64$ (cluster C3) and BR (cluster C1), and the highest GDP_C (cluster C3) and PLMP (cluster C1). More specifically, there were low performances accounted by 15 countries enclosed into $\mathrm{C} 4$ (mainly, countries of the new EU-13, aside from Greece, which registered the lowest economic welfare, GDP_C, from the EU-27 MS in relation with negative implications of PLMP, BR and $L E$, although the ER_55_64 and OD_65 was medium), and C5 clusters (despite the highest level of $L E$ and $B R$ ).

Table 1 Clusters associated with the economic welfare (GDP per capita), ageing phenomenon and labour market indicators, EU-27, 2018

\begin{tabular}{|c|c|c|}
\hline \multicolumn{2}{|c|}{$\begin{array}{l}\text { Clusters EU-27 } \\
\text {. }\end{array}$} & Cluster Modelling - Ward Method \\
\hline (C) & Member States & Performance \\
\hline $\mathrm{C} 1$ & $\begin{array}{l}\text { Italy, France, Spain, the Netherlands, } \\
\text { Finland, Germany, Belgium, Portugal, } \\
\text { Austria }\end{array}$ & $\begin{array}{l}\text { Medium (particularly in terms of } G D P \_C \text {, } \\
E R \_55 \_64, A L M P, P L M P \text { and } L E \text {, but low in } \\
\text { terms of } B R \text { and high } O D \_65 \text { ) }\end{array}$ \\
\hline $\mathrm{C} 2$ & Denmark, Sweden & $\begin{array}{l}\text { Very High (extremely significant in terms of } \\
E R \_55 \_65 \text { and } A L M P \text {, but also } G D P \_C, L E \text {, } \\
P L M P \text { and } B R \text { ) }\end{array}$ \\
\hline $\mathrm{C} 3$ & Luxembourg & $\begin{array}{l}\text { Medium to high (particularly through high levels } \\
\text { of } G D P \_C, A L M P \text { and } L E \text {, and the lowest } O D \_65 \text {, } \\
\text { despite reduced } E R \_55 \_64, B R \text { and } P L M P \text { ) }\end{array}$ \\
\hline $\mathrm{C} 4$ & $\begin{array}{l}\text { Lithuania, the Czech Republic, Hungary, } \\
\text { Greece, Bulgaria, Poland, Romania, } \\
\text { Slovenia, the Slovak Republic, Latvia, } \\
\text { Estonia, Malta, Croatia }\end{array}$ & $\begin{array}{l}\text { Low (in terms of the lowest } G D P \_C, P L M P, B R \\
\text { and } L E \text {, and also reduced } A L M P \text {, despite } \\
\text { medium } E R \_55 \_64 \text {, and } O D \_65 \text { ) }\end{array}$ \\
\hline $\mathrm{C} 5$ & Ireland, Cyprus & $\begin{array}{l}\text { Low to medium (particularly through medium } \\
\text { levels of } E R \_55 \_64, L E \text {, despite the highest } \\
\text { level of } L E \text { and } B R \text {, and low level of } G D P \_C \text {, } \\
A L M P, P L M P \text { and } O D \_65 \text { ) }\end{array}$ \\
\hline
\end{tabular}

Based on these findings, we can assert that there are significant dissimilarities between the EU-27 MS in terms of economic welfare connected to ageing phenomenon and labour market implications, the developing countries facing low performances compared to the developed ones, our hypothesis, $\mathrm{H}$, being validated.

\section{CONCLUSIONS}

By applying the cluster modelling, for testing our research hypothesis, we have pursued for dissimilarities grouping between the EU-27 MS, thus: the lowest performance related to ageing, economic welfare and labour market was registered for the new EU-13 MS (including also Greece from the old EU-14 countries), and the highest, for the Nordic States (Sweden and Denmark); overall, the EU-13 countries are confronting with low performances compared to the EU-14 MS.

These findings are based on the fact that the Nordic States (Denmark and Sweden) "are well known for their labour market models and best practices at European level (namely the 'Danish model' of flexicurity) focused on balancing flexibility and security for a proper professional and personal development of employees and an adequate labour market insertion and integration (inclusion)" (Noja \& Cristea, 2018, p. 735). The Danish labour market policies are justified by 
the fact that ,each person should, when possible, be active and participate in the social life by working or by attending activation initiatives" (Bazzani, 2017, p. 138). As main policies and strategies as regards ageing and welfare, the good practices of the Nordic countries consist in „activity centres” dedicated for the older people, with entailing them in governance of these centers, making them ,empowered to define meaningfulness in activities, but only as an active member of a community" (Evans et al., 2018, p. 1).

Main limitations of the research conducted in this paper may infer the cross-sectional analysis performed at the level of one year that needs to be complemented with a panel-data analysis in order to be further advanced through accurate policies, including by accounting the implications upon the business environment (Pirtea et al., 2014), this type of analysis being targeted as main direction in our future research.

\section{REFERENCES}

Bazzani, T. (2017). Italy, Denmark and Germany: A comparative analysis in active and passive labour market policies. European Labour Law Journal, 8 (2), 133-153. https://doi.org/10.1177/2031952517712124

Calvo-Sotomayor, I., Laka, J. P., \& Aguado, R. (2019). Workforce ageing and labour productivity in Europe. Sustainability, 11 (20), 5851. https://doi.org/10.3390/su11205851

Conde-Sala, J. L., Portellano-Ortiz, C., Calvó-Perxas, L., \& Garre-Olmo, J. (2017). Quality of life in people aged 65+ in Europe: Associated factors and models of social welfare - analysis of data from the SHARE project (Wave 5). Quality of Life Research, 26, 1059-1070. https://doi.org/10.1007/s11136-016-1436-x

Cornish, R. (2007). Statistics: cluster analysis. Mathematics Learning Support Centre, 1-5.

Cristea, M., Noja, G. G., Dănăcică, D. E., \& Ștefea, P. (2020a). Population ageing, labour productivity and economic welfare in the European Union. Economic Research - Ekonomska Istraživanja,33 (1), 1354-1376. https://doi.org/10.1080/1331677X.2020.1748507

Cristea, M., Noja, G. G., Ponea, S., \& Banaduc, I. (2020b). Labor productivity in the complex interplay between health and well-being of older employees: A focus on the New European Union Member States under the Covid-19 pandemic crisis. Economic and Social Development: Book of Proceedings, 69-78.

European Commission, (2020a). Eurostat Database. Retrieved from: http://ec.europa.eu/eurostat/data/database, Accessed on: 16 September 2020.

European Commission, (2020b). Employment, Social Affairs \& Inclusion. Statistical data. Retrieved from: https://ec.europa.eu/social/main.jsp?catId=1143\&intPageId=3227\&langId=en_Accessed on: 16 September 2020.

Evans, A. B., Nistrup, A., \& Pfister, G. (2018). Active ageing in Denmark; Shifting institutional landscapes and the intersection of national and local priorities. Journal of aging studies, 46, 1-9. https://doi.org/10.1016/j.jaging. 2018.05.001

Härdle, W. K., \& Simar, L. (2019). Applied multivariate statistical analysis 5th edition, Switzerland: Springer, Cham. https://doi.org/10.1007/978-3-030-26006-4_13

Jivraj, S., Goodman, A., Pongiglione, B., \& Ploubidis, G. B. (2020). Living longer but not necessarily healthier: The joint progress of health and mortality in the working-age population of England. Population Studies, 74 (3), $399-414$. https://doi.org/10.1080/00324728.2020.1767297

Kashnitsky, I., \& Aburto, J. M. (2020). COVID-19 in unequally ageing European regions. World development, 136, 105170. https://doi.org/10.1016/j.worlddev.2020.105170

Maestas, N., Mullen, K. J., \& Powell, D. (2016). The effect of population aging on economic growth, the labour force and productivity. National Bureau of Economic Research, Inc., Working Paper Series No. 22452, Retrieved from: https://www.nber.org/papers/w22452 Accessed on: 02 October 2020.

McKibbin, W., \& Fernando, R. (2020). The economic impact of COVID-19. In: Baldwin, R. \& Weder di Mauro, B. (Eds.), Economics in the Time of COVID-19 (pp. 45-52). London: Centre for Economic Policy Research (CEPR).

Noja, G. G., \& Cristea, M. (2018). Working conditions and flexicurity measures as key drivers of economic growth: Empirical evidence for Europe. Ekonomicky Casopis (Journal of Economics), 66 (7), 719-749.

Pirtea, M., Nicolescu, C., \& Botoc, C. (2014). Do Romanian Companies Follow Pecking Order Financing?. Economic Computation and Economic Cybernetics Studies and Research 48 (1), 1-15.

Rovan, J., \& Sambt, J. (2003). Socio-economic differences among Slovenian municipalities: A cluster analysis approach. Development in Applied Statistics, 19, 265-278.

Sidlo, L., Sprocha, B., \& Durcek, P. (2020). A retrospective and prospective view of current and future population ageing in the European Union 28 countries. Moravian Geographical Reports, 28 (3), 187-207. https://doi.org/10.2478/mgr2020-0014 
Skufina, T., Baranov, S., \& Samarina, V. (2020). Modeling and forecasting GDP production in russia, taking into account changes in the number of working-age population caused by the retirement age increasing. In: Solovev D., Savaley V., Bekker A. \& Petukhov V. (Eds.), Proceeding of the International Science and Technology Conference "FarEastCon 2019". Smart Innovation, Systems and Technologies, 172 (pp. 201-209). Singapore: Springer. https://doi.org/10.1007/978-981-15-2244-4_17

UNECE/European Commission, (2019). 2018 Active Ageing Index: Analytical report. Report prepared by Giovanni Lamura and Andrea Principi, Geneva, June. Retrieved from: https://www.unece.org/fileadmin/ DAM/pau/age/Active_Ageing_Index/Stakeholder_Meeting/ACTIVE_AGEING_INDEX_TRENDS_20082016_web_cover_reduced.pdf Accessed on: 02 September 2020.

Thalassinos, E., Cristea, M., \& Noja, G. G. (2019). Measuring active ageing within the European Union: Implications on economic development. Equilibrium. Quarterly Journal of Economics and Economic Policy, 14 (4), 591-609. https://doi.org/10.24136/eq.2019.028

The World Bank, (2020). World Development Indicators, Retrieved from: https://databank.worldbank.org/ reports.aspx?source=world-development-indicators Accessed on: 12 September 2020.

Wolf, M. (2020). Why inflation could be on the way back, Financial Review, Retrieved from: https://www.afr. com/policy/economy/why-inflation-could-be-on-the-way-back-20201118-p56fle Accessed on: 10 September 2020 .

\section{RAZLIKE U STARENJU POPULACIJE I BLAGOSTANJU UNITAR EVROPSKE UNIJE: NOVI PRISTUP ZASNOVAN NA KLASTER ANALIZI}

Ovo istraživanje ima za cilj da identifikuje nekoliko razlika među zemljama članicama Evropske unije (EU-27 MS) u pogledu dimenzija blagostanja i tržišta rada pod implikacijama fenomena starenja. Metodologija kvantitativnog istraživanja naglašava klaster analizu zasnovanu na Vard-ovoj metodi za 2018. godinu. Glavni rezultati ukazuju da su samo dve zemlje (Danska i Švedska) registrovale visoke preformanse, naročito za akreditive na tržištu rada (konkretno stopa zaposlenosti i aktivne politike). Ostalih deset EU-27 zemalja su pokazale srednje performanse u smislu blagostanja, ali $i$ najniža postignuća u smislu stope zavisnosti starih, stope zaposlenosti osoba između 55 i 64 godina starosti $i$ nataliteta. Ovaj rad iznosi u prvi plan jaku potrenu da se ponovo osmisle konkretne politike $i$ prilagođene strategije od strane nadležnih institucija i biznis predstavnika širom EU, da bi se naglasila postignuća i nova rešenja za izazove nastale starenjem populacije, sa efektima prelivanja na integraciju starijih zaposlenih u tržište rada i sveukupno ekonomsko blagostanje. Rad se ističe novim integrativnim pristupom baziranim na klaster analizi koja naglašava razlike među zemljama članicama EU, $i$ karaktereistike svake grupe zemalja, unutar unapred utvrđenog okvira, ističući tako poteškoće, ali $i$ mogućnosti koje se pružaju u pogledu starenja i ekonomskog blagostanja.

Ključne reči: tržište rada, ekonomski razvoj, demografsa ekonomija, klaster analiza

\section{APPENDIX}

Table A1 Clusters results for the implications of the aging phenomenon and labour market policies upon the GDP per capita, EU-27, 2018

\begin{tabular}{|c|c|c|c|c|c|c|c|c|c|c|c|c|c|c|c|c|c|}
\hline \multirow{2}{*}{ Indicators } & \multicolumn{3}{|c|}{ Cluster 1 (C1) } & \multicolumn{3}{|c|}{ Cluster 2 (C2) } & \multicolumn{3}{|c|}{ Cluster 3 (C3) } & \multicolumn{3}{|c|}{ Cluster 4 (C4) } & \multicolumn{3}{|c|}{ Cluster 5 (C5) } & \multirow[b]{2}{*}{$F$} & \multirow{2}{*}{ R-sq } \\
\hline & $\mathrm{N}$ & $\mathrm{N}$ mean & sd & $\mathrm{N}$ & mean & sd & $\mathrm{N}$ & mean & sd & $\mathrm{N}$ & mean & sd & $\mathrm{N}$ & mean & sd & & \\
\hline$\overline{\text { GDP_C }}$ & & 0.6719 & 0.4892 & 2 & 1.5704 & 0.2080 & 1 & 4.0341 & & 13 & -0.5037 & 0.2812 & 2 & -0.2496 & 0.5194 & $47.24045^{* * * *}$ & 0.8957 \\
\hline ER_55_64 & 9 & 1.0724 & 0.6265 & 2 & 2.2866 & 0.4993 & 1 & -0.3690 & & 13 & 0.7850 & 0.7891 & 2 & 1.2476 & 0.0283 & $3.011615^{* *}$ & 0.3538 \\
\hline OD_65 & 9 & 1.6459 & 0.6118 & 2 & 1.5355 & 0.2615 & 1 & -0.8447 & & 13 & 1.1569 & 0.6995 & 2 & -0.4519 & 0.3595 & $7.052035^{* *}$ & 0.5618 \\
\hline ALMP & & 0.3614 & 0.5981 & 2 & 2.4618 & 1.3343 & 1 & 0.6421 & & 13 & -0.5035 & 0.5138 & 2 & -0.6214 & 0.5957 & $11.94874^{* * *}$ & 0.6848 \\
\hline PLMP & 9 & 1.2150 & 0.6932 & 2 & 0.1321 & 0.7225 & 1 & -0.2020 & & 13 & -0.7567 & 0.2967 & 2 & -0.2118 & 0.3751 & $20.63566^{* * *}$ & 0.7896 \\
\hline LE & 9 & 1.2770 & 0.2590 & 2 & 1.1691 & 0.3328 & 1 & 1.3162 & & 13 & 0.0601 & 0.7672 & 2 & 1.4045 & 0.1248 & $7.2119^{* *}$ & 0.5673 \\
\hline $\mathrm{BR}$ & 9 & -0.8760 & 0.8314 & 2 & 0.2973 & 0.3733 & 1 & -0.1647 & & 13 & -0.5150 & 0.5438 & 2 & 0.6932 & 0.8399 & $3.040925^{* *}$ & 0.3560 \\
\hline
\end{tabular}

Source: own process of panel data in Stata 